\title{
SIMULASI NUMERIK PADA ALAT PENGERING BIJI KOPI TENAGA SURYA
}

\author{
Adolf Ronny ${ }^{1 *}$, Himsar Ambarita ${ }^{2}$, Farel H. Napitupulu ${ }^{3}$, M. Syahril Gultom ${ }^{4}$ \\ ${ }^{1,2,3,4}$ Departemen Teknik Mesin, Fakultas Teknik, Universitas Sumatera Utara \\ Email: Adronny10@gmail.com
}

\begin{abstract}
In this study comparing the efficiency of coffee bean dryers that have been tested experimentally. The dryer design consists of two solar collector units, one drying chamber with three shelves, and 2 solar powered fans located at the dryer outlet. The dryer was designed and conducted an experimental test at the USU Department of Mechanical Engineering. Computational Fluid Dynamics (CFD) is used to determine the temperature distribution that occurs in the dryer. From the templates distribution, tips can calculate the efficiency of the dryer numerically. After calculating, it is found that the efficiency of the solar collector is $77 \%$ and the setting ring is $89 \%$. Whereas experimentally the efficiency of solar collectors is $74 \%$ and the drying chamber is $90 \%$
\end{abstract}

Abstrak

Dalam penelitian ini membandingkan efisiensi alat pengering biji kopi yang telah diuji eksperimental. Desain pengering terdiri dari dua unit kolektor surya, satu ruang pengering dengan tiga rak, dan 2 kipas bertenaga surya yang terletak di saluran keluar pengering. Pengering dirancang dan dilakukan uji eksperimental di Departemen Magister Teknik Mesin USU . Computational Fluid Dynamics (CFD) digunakan untuk mengetahui distribusi temperature yang terjadi di alat pengering. Dari distribusi temerpatur tersebut kiat dapat menghitung efisiensi dari alat pengering secara numerik.Setelah dihitung didapatkan bahwa efisiensi dari kolektor surya $77 \%$ dan ruan penegering $89 \%$. Sedangkan secara eksperimental efisiensi kolektor surya $74 \%$ dan ruang pengering $90 \%$

\section{PENDAHULUAN}

Sebagai salah satu negara penghasil kopi terbesar dunia di urutan ke-4, Indonesia harus bisa memanfaatkan peluang besar yang ada untuk bisa meningkatkan kualitas dan juga kuantitas produksi kopi. Pengeringan adalah proses penghilangan massa air dari suatu benda dengan penguapan kandungan air yang ada pada benda tersebut. Namun pengeringan cara konvensional ini memiliki permasalahan pada saat saat cuaca mendung atau hujan ssehingga dibutuhkan suatu alat sebagai media pengering dan juga penjaga keadaan udara.

Dengan bantuan CFD memudahkan kita untuk mengembangkan dan membandingkan rancangan yang telah dibuat. Oleh sebab itu penulis menggunakna Software ANSYS untuk membandingkan hasil eksperimental dan simulasi numerik pada alat pengering biji kopi

\section{TEORI DASAR}

\subsection{Energi Surya}

Energi surya adalah salat satu sumber energi terbarukan dan berkelanjutan karena keberadaanya yang tidak akan habis. Energi surya sampai ke bumi dalam bentuk energi panas dengan prinsip perpindahan panas radiasi. Sebagai energi terbarukan, energi surya semakin lama semakin dikembangkan agar bisa dimanfaatkan lebih lagi.

Matahari mempunyai diameter $1,39 \times 109 \mathrm{~m}$. Bumi mengelilingi matahari dengan lintasan berbentuk ellipse dan matahari berada pada salah satu pusatnya. Jarak rata-rata matahari dari permukaan bumi adalah $1,49 \times 1011 \mathrm{~m}$. Lintasan bumi terhadap matahari berbentuk ellipse, maka jarak antara bumi dan matahari adalah tidak konstan. Karena adanya perbedaan jarak ini, menyebabkan radiasi yang diterima atmosfer bumi juga akan berbeda 


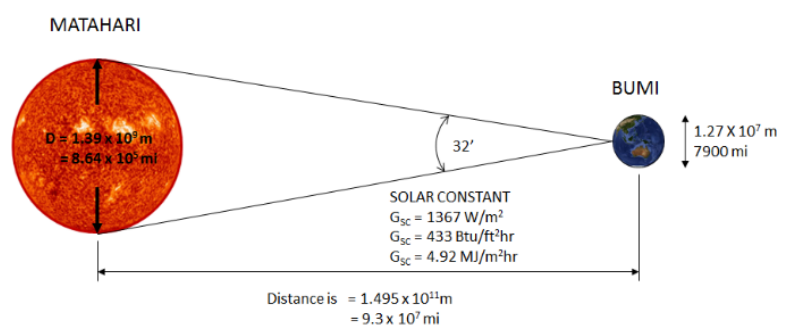

Gambar 2.1 Hubungan Matahari dan Bumi

\subsection{Pengeringan Tenaga Surya (Solar Dryer)}

Pengeringan adalah proses pengurangan kadar air yang relatif kecil secara terusmenerus pada suatu bahan. Metode pengeringan dengan energi matahari secara umum terbagi atas dua, yaitu pengeringan sinar matahari (direct sun drying), dimana produk yang akan dikeringkan langsung dijemur di bawah sinar matahari. Dan metode pengeringan surya (solar drying), dimana produk yang akan dikeringkan diletakkan di dalam suatu alat pengering.

Pengering tenaga surya (solar dryer) adalah cara pengeringan dengan memanfaatkan energi matahari menggunakan kolektor sebagai penyerap panas yang menjadikan penggunaan energi matahari yang lebih maksimal.

\subsection{Kolektor Surya}

Pengering surya adalah suatu sistem pengering yang memanfaatkan energi surya. Sistem pengering surya terdiri dari dua bagian utama yaitu kolektor surya dan ruang pengering. Kolektor surya adalah suatu alat yang dapat mengumpulkan atau menyerap radiasi surya dan mengkonversikan menjadi panas.

Kolektor surya dapat didefinisikan sebagai sistem perpindahan panas yang menghasilkan energi panas dengan memanfaatkan radiasi sinar matahari sebagai sumber energi utama. Kolektor surya yang pada umumnya memiliki komponen-komponen utama, yaitu:

1. Cover berfungsi untuk mengurangi rugi panas secara konveksi menuju lingkungan.

2. Absorber berfungsi untuk menyerap panas dari radiasi cahaya matahari.

3. Kanal berfungsi sebagai saluran transmisi fluida kerja.

4. Isolator berfungsi meminimalisasi kehilangan panas secara konduksi dari absorber menuju lingkungan.

5. Frame berfungsi sebagai struktur pembentuk dan penahan beban kolektor.

\subsection{Teori Perpindahan Panas}

Panas adalah salah satu bentuk energi yang dapat dipindahkan dari suatu tempat ke tempat lain, tetapi tidak dapat diciptakan atau dimusnahkan sama sekali. Dalam suatu proses, panas dapat mengakibatkan terjadinya kenaikan suhu suatu zat dan atau perubahan tekanan, reaksi kimia dan kelistrikan. Perpindahan kalor/panas (heat transfer) ialah ilmu untuk meramalkan perpindahan energi yang terjadi karena adanya perbedaan suhu di antara benda atau material. Dimana perpindahan panas ini merupakan satu dari disiplin ilmu teknik termal yang mempelajari cara menghasilkan panas, menggunakan panas, mengubah panas, dan menukarkan panas di antara sistem fisik. Proses terjadinya perpindahan panas dapat dilakukan secara langsung, yaitu fluida yang panas akan bercampur secara langsung dengan fluida dingin tanpa adanya pemisah dan secara tidak langsung, yaitu bila diantara fluida panas dan fluida dingin tidak berhubungan langsung tetapi dipisahkan oleh sekat-sekat pemisah. Frank Kreith dan Mark S. Bohn dalam bukunya mengklasifikasikan perpindahan panas dalam tiga bahagian yaitu : konduksi, konveksi, radiasi. Dimana ketiga hal tersebut dapat di ilustrasi dari proses sederhana berikut. 


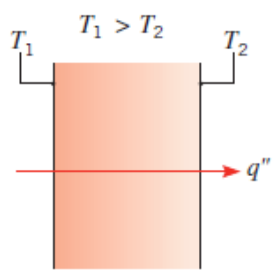

Gambar 2.3 Perpindahan panas secara konduksi

Dari gambar 2., dengan memperhatikan material batang, sebagai contoh plastik, akan ditemukan bahwa kesebandingan diatas adalah valid. Namun, kita juga menemukan bahwa untuk nilai $A, \Delta x$, dan $\Delta T$ yang sama, akan menghasilkan nilai $q_{x}$ yang lebih kecil untuk material plastik dibandingkan bermaterial logam. Sehingga kesebandingan diatas dapat ditulis dalam bentuk persamaan dengan memasukkan koefisien yang dipengaruhi oleh material. Berdasarkan pada hukum Fourier, persamaan 2.2, konduktifitas termal didefenisikan sebagai :

$$
k=\frac{q_{k} / A}{|d T / d x|}
$$

$k$ adalah konduktivitas thermal (W/m.K), yang merupakan sifat material yang penting karena sangat mempengaruhi nilai perpindahan panas yang terjadi pada sebuah benda. Berikut merupakan nilai konduktivitas panas untuk beberapa material :

\subsubsection{Perpindahan Panas Konveksi}

Konduksi dan konveksi adalah membutuhkan media perantara dalam proses perpindahan panasnya. Namun pada konveksi membutuhkan gerakan fluida untuk dapat memindahkan panas. Penelitian menunjukkan bahwa perpindahan panas konveksi sangat bergantung pada sifat-sifat fluida seperti viskositas dinamis $\mu$, konduktivitas termal $k$, massa jenis $\rho$, dan spesifik panas $C_{p}$, dan dipengaruhi oleh kecepatan fluida $V$. Konveksi juga bergantung pada bentuk dan kekasaran permukaan, dan bahkan juga dipengaruhi oleh tipe aliran seperti laminar atau turbulen. Sehingga dapat disimpulkan bahwa perpindahan panas secara konveksi adalah kompleks karena bergantung pada banyak variabel. Oleh karena itu, konveksi adalah mekanisme perpindahan panas yang paling kompleks. Meskipun konveksi adalah kompleks, setelah diamati bahwa laju perpindahan panas secara konveksi berbanding lurus dengan perbedaan temperatur dan dapat ditulis dengan Hukum Newton tentang pendinginan. Berikut adalah skematik perpindahan panas secara konveksi :

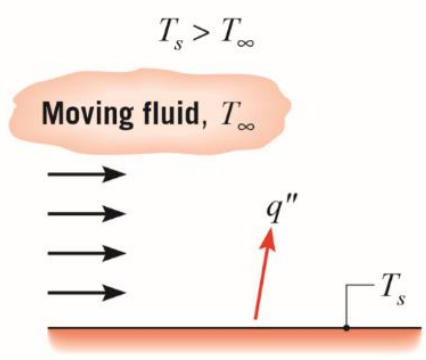

Gambar 2.4 Perpindahan panas secara konveksi

Untuk nilai perpindahan panas secara konveksi dapat di tentukan dengan rumus:

$$
q_{\text {konveksi }}=h A_{s}\left(T_{s}-T_{\infty}\right)
$$

dengan $\quad h$ : koefisien perpindahan panas konveksi $\left(\mathrm{W} / \mathrm{m}^{2} \mathrm{~K}\right)$

$A_{s}$ : luas permukaan perpindahan panas $\left(\mathrm{m}^{2}\right)$

$T_{s}$ : temperatur permukaan benda $(\mathrm{K})$

$T_{\infty}$ : merupakan temperatur lingkungan sekitar benda

\subsubsection{Perpindahan Panas Radiasi}

Radiasi berbeda dengan mekanisme perpindahan panas secara konduksi dan secara konveksi. Perpindahan panas secara radiasi tidak membutuhkan kehadiran suatu material 
sebagai media perantara perpindahan panas. Faktanya, energi yang ditransfer dengan radiasi adalah yang tercepat (secepat kecepatan cahaya) dan dapat terjadi pada ruangan vakum. Perpindahan panas secara konduksi dan konveksi terjadi dari temperatur yang tinggi ke temperatur yang lebih rendah. Pada radiasi, perpindahan panas dapat terjadi pada 2 benda yang memiliki temperatur yang tinggi dan dipisahkan oleh benda yang memiliki temperatur yang lebih rendah. Berikut merupakan skematik proses terjadinya perpindahan panas secara radiasi :

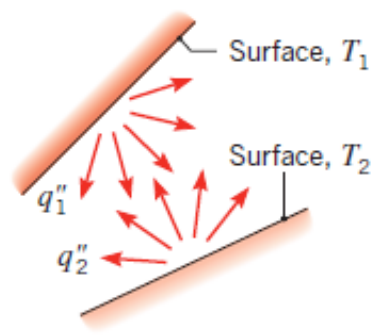

Gambar 2.5 Proses perpindahan panas radiasi

Joseph Stefan dan Boltzmann menetapkan sebuah hukum yang ditetapkan secara eksperimental untuk menentukan besarnya energi radiasi yang dipancarkan oleh sebuah blackbody yang disebut dengan hukum Stefan-Boltzmann.

$$
Q_{\text {radiasi }}=\sigma A T^{4} \text {. }
$$

Dimana $\sigma=5,669 \times 10^{-8} \mathrm{~W} / \mathrm{m}^{2} \mathrm{~K}^{4}$ adalah konstanta proporsionalitas dan disebut konstanta Stefan-Boltzmann dan $T$ adalah temperatur absolut dari suatu permukaan (K).

\subsection{Teori dan Persamaan Dasar Sistem Kolektor Plat Datar}

Radiasi matahari diserap oleh absorber plat hitam, kemudian panas yang dihasilkan ditransfer ke fluida kerja yang mengalir dalam pipa-pipa di bawah absorber. Pemakaian absorber plat hitam tersebut dimaksudkan untuk mengisolasi energi radiasi surya yang sudah mengenai absorber dengan maksimal ditransfer ke fluida kerja. Keseimbangan energi panas pada kolektor plat datar pada persamaan berikut yaitu [3]:

Keterangan:

$$
Q=A_{c}\left[(\tau \alpha) \dot{e} S-U_{L}\left(T_{p m}-T_{a}\right)\right]
$$

$$
\begin{array}{ll}
A_{c} & =\text { luas permukaan kolektor }\left(\mathrm{m}^{2}\right) \\
U_{L} & =\text { koefisien kehilangan panas kolektor }\left(\mathrm{W} / \mathrm{m}^{2} . \mathrm{K}\right) \\
T_{p m} & =\text { temperatur permukaan plat } / \text { Temperatur absorber }(\mathrm{K}) \\
T_{a} & =\text { temperatur udara lingkungan/ Temperatur ambient }(\mathrm{K}) \\
S & =\text { energi radiasi matahari }\left(\mathrm{W} / \mathrm{m}^{2}\right) \\
\tau \alpha & =\text { koefisien transmisi-absorber }
\end{array}
$$

2.5.1 Koefisien kerugian kalor total (Overall Heat Loss Coefficient)

Kerugian kalor dari absorber terjadi pada bagian atas, samping dan bawah absorber, sehingga persamaannya menjadi:

$$
U_{L}=U_{t}+U_{b}+U_{e} .
$$

Keterangan:

$$
\begin{array}{ll}
U_{L} & =\text { koefisien kerugian kalor total } \\
U_{t} & =\text { koefisien kerugian kalor bagian atas } \\
U_{b} & =\text { koefisien kerugian kalor bagian bawah } \\
U_{e} & =\text { koefisien kerugian kalor bagian samping } \\
\text { 2.5.2 } & \text { Kerugian kalor bagian atas }
\end{array}
$$

Panas yang hilang dari bagian atas plat penyerap karena adanya konveksi alam dan radiasi dari bagian dalam plat kolektor ke permukaan kaca. Dan panas ini dikonduksikan melalui kaca ke permukaan luarnya yang kemudian dipindahkan ke atmosfer luar secara konveksi dan radiasi. Namun biasanya pada plat kolektor, kerugian kalor secara konduksi 
diabaikan sebab tebal cover dan sirip plat absorber kecil sehingga perbedaan temperatur tidak begitu signifikan.

Nilai koefisien kerugian kalor bagian atas secara teori dapat didekati dengan persamaan berikut:

$U_{t}$

$$
\begin{aligned}
& =\frac{1}{R_{p-c 1}+R_{c 1-c 2}+R_{c 2-a}} \\
& =\frac{1}{\frac{1}{h_{c, p-c 1}+h_{r, p-c 1}}+\frac{1}{h_{c, c 1-c 2}+h_{r, c 1-c 2}}+\frac{1}{h_{w}+h_{r, c 2-a}}} .
\end{aligned}
$$

Dimana dengan mempergunakan persamaan empiris S.A. Klein yang telah dimodifikasi oleh Agarwal dan Larson, maka kerugian kalor bagian atas dapat dicari menggunakan persamaan 2.8, yaitu:

$$
U t=\left\{\frac{N}{\frac{C}{T_{p}}\left[\frac{\left(T_{p}+T_{a}\right)}{(N+f)}\right]}+\frac{1}{h_{w}}\right\}^{-1}+\frac{\sigma\left(T_{p}+T_{a}\right)\left(T_{p}^{2}+T_{a}^{2}\right)}{\left[\varepsilon_{p}+0.05 N\left(1-\varepsilon_{p}\right)\right]^{-1}+\frac{2 N+f-1}{\varepsilon_{c}} N} \ldots \ldots .
$$

Dengan:

$$
\begin{array}{ll}
h_{w} & =5.7+3.8 v\left(\mathrm{~W} / \mathrm{m}^{2} . \mathrm{K}\right) \\
f & =\left(1-0.04 h_{w}+0.0005 h_{w}\right)(1+0.091 N) \\
C & =520\left(1-0.000051 \beta^{2}\right)
\end{array}
$$

Keterangan:

$v \quad=$ kecepatan angin di atas permukaan cover paling atas $(\mathrm{m} / \mathrm{s})$

$N \quad=$ jumlah penutup

$\varepsilon_{c} \quad=$ emisivitas cover

$\varepsilon_{p} \quad=$ emisivitas plat absorber

$\sigma \quad=$ konstanta Stefan-Boltzman $\left(5.67 \times 10^{-8} \mathrm{~W} / \mathrm{m}^{2} \cdot \mathrm{K}^{4}\right)$

$T_{p} \quad=$ temperatur plat absorber $(\mathrm{K})$

$T_{a} \quad=$ temperatur lingkungan $(\mathrm{K})$

\subsubsection{Kerugian kalor bagian bawah}

Kerugian kalor pada bagian bawah terjadi secara konduksi dari absorber ke panel bawah (bottom of panel), sedangkan kerugian konveksi dan radiasi diabaikan sebab nilainya lebih kecil dibandingkan kerugian secara konduksi.

Nilai koefisien kerugian kalor bagian bawah didekati dengan persamaan 2.10 berikut:

$$
U_{b}=k . L \text {. }
$$

Keterangan:

$k=$ konduktivitas termal insulator bagian bawah

$L \quad=$ tebal insulator

2.5.4 Kerugian Kalor Pada Bagian Samping

Nilai koefisien kerugian kalor bagian samping juga didekati dengan persamaan 2.11 berikut:

$$
U_{e}=\frac{(U A)_{e d g e}}{A_{c}} \text {. }
$$

Keterangan:

$U_{A} \quad=\mathrm{k} / \mathrm{L} \mathrm{x}$ keliling kolektor $\mathrm{x}$ ketebalan kolektor

Ac $\quad=$ luas permukaan kolektor $\left(\mathrm{m}^{2}\right)$

\subsubsection{Efisiensi Kolektor}

Efisiensi dari kolektor dapat didefinisikan sebagai perbandingan antara panas yang berguna dari kolektor dengan intensitas dari radiasi surya pada persamaan sebagai berikut:

Keterangan:

$$
\begin{gathered}
\eta=\frac{q_{u s e}}{S . A_{c}}=F_{R}\left[(\tau \alpha)_{\dot{\mathrm{e}}}-F_{R} U_{L}\left(\frac{\left(T_{i}-T_{a}\right)}{S}\right)\right] \ldots . \\
\eta=\frac{q_{u s e}}{S . A_{c}}=F^{\prime}\left[(\tau \alpha)_{\dot{\mathrm{e}}}-F^{\prime} U_{L}\left(\frac{\left(T_{i}-T_{a}\right)}{S}\right)\right] \ldots
\end{gathered}
$$

$$
\begin{array}{ll}
\eta & =\text { efisiensi kolektor }(\%) \\
q_{u s e} & =\text { laju perpindahaan panas pada kolektor } \\
A_{c} & =\text { luas permukaan kolektor }\left(\mathrm{m}^{2}\right)
\end{array}
$$




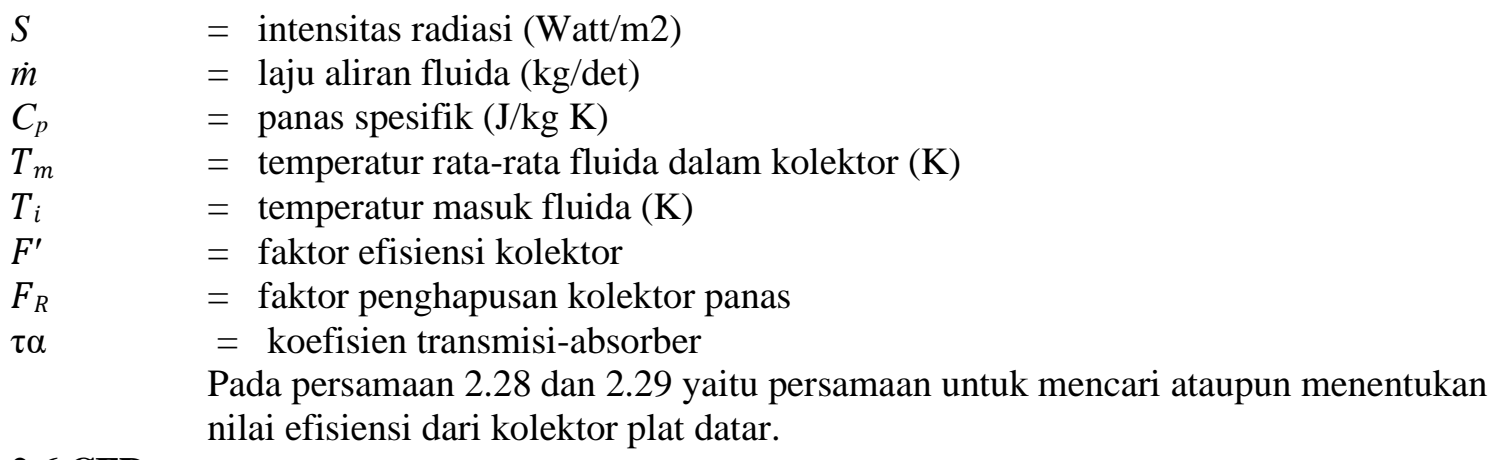

\subsection{CFD}

Computational system dynamics (CFD) adalah analisis sistem yang melibatkan aliran fluida, perpindahan panas, dan fenomena terkait seperti reaksi kimia melalui simulasi berbasis komputer. Teknik ini sangat kuat dan mencakup berbagai area aplikasi industri dan nonindustri. Beberapa contoh adalah: aerodinamika pesawat terbang dan kendaraan, hidrodinamika kapal, pembakaran, mesin turbo, teknik listrik dan elektronik, teknik proses kimia, lingkungan eksternal dan internal bangunan, teknik kelautan, teknik lingkungan, hidrologi dan oseanografi, metrologi, teknik biomedis dll. Sejak 1960-an dan seterusnya, industri kedirgantaraan telah mengintegrasikan teknik CFD ke dalam desain, $R \& D$, dan pembuatan pesawat terbang dan mesin jet. Baru-baru ini metode telah diterapkan pada desain mesin pembakaran internal, ruang pembakaran turbin gas dan tungku. Selain itu, pabrikan motor sekarang secara rutin memprediksi gaya seret, di bawah aliran udara bonnet dan lingkungan dalam mobil dengan CFD. CFD semakin menjadi komponen penting dalam desain produk dan proses industri. Tujuan utama pengembangan di bidang CFD adalah untuk memberikan kemampuan yang sebanding dengan alat CAE (ComputerAided Engineering) lainnya seperti kode analisis stres.

Alasan utama mengapa CFD tertinggal adalah kompleksitas luar biasa dari perilaku yang mendasari, yang menghalangi deskripsi aliran fluida ini pada saat yang sama ekonomis dan cukup lengkap. Ketersediaan perangkat keras komputasi kinerja tinggi yang terjangkau dan pengenalan gangguan yang ramah pengguna telah menyebabkan peningkatan minat baru-baru ini dan CFD siap untuk membuat masuk ke komunitas industri yang lebih luas di tahun 1990an. Jelas biaya investasi kemampuan CFD tidak kecil, tetapi total biaya biasanya tidak sebesar biaya fasilitas eksperimental yang berkualitas tinggi. Selain itu, ada beberapa keuntungan unik CFD dibandingkan pendekatan berbasis eksperimental untuk desain sistem fluida. 1. Pengurangan besar waktu tunggu dan biaya desain baru. 2. Kemampuan untuk mempelajari sistem di mana eksperimental terkontrol sulit atau tidak mungkin dilakukan. (mis. sistem yang sangat besar) 3. Kemampuan untuk mempelajari sistem dalam kondisi berbahaya pada dan di luar batas kinerja normal. (mis. studi keselamatan dan skenario kecelakaan) 4. Praktik tingkat detail hasil yang tidak terbatas. Sebaliknya kode CFD dapat menghasilkan volume hasil yang sangat besar tanpa biaya tambahan dan sangat murah untuk melakukan studi parametrik, misalnya untuk mengoptimalkan kinerja peralatan

Kode CFD disusun di sekitar algoritma numerik yang dapat mengatasi masalah aliran fluida. Untuk memberikan penilaian yang mudah terhadap kekuatan penyelesaiannya, semua paket CFD komersial mencakup antarmuka pengguna yang canggih untuk memasukkan parameter masalah dan memeriksa hasilnya. Karenanya semua kode mengandung tiga elemen utama:

1. Pre-processing

2. Processing

3. Post-processing

III. HASIL DAN PEMBAHASAN

\subsection{Pre-Processing}

Desain dari analisa adalah aliranfluida yang mengalir pada alat pengering tersebut. Adapun aliran geometri dapat dilihat pada gamabr dibawah ini 

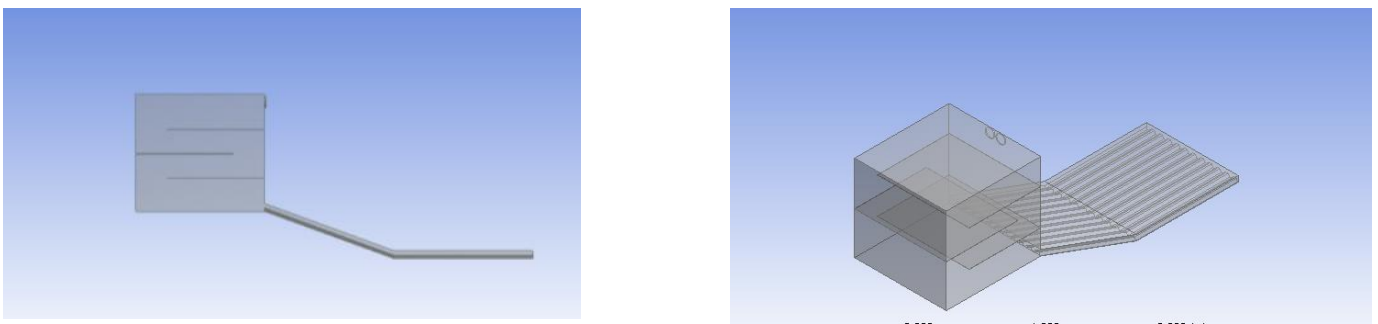

Gambar 3.1 Geometri alat pengering biji kopi

Ansys Meshing digunakan untuk membentuk mesh pada tiap bagian geometri. Adapun bentuk mesh yang digunakna adalah mesh dengan pengaturan default oleh Ansys Meshing sudah dibentuk dan perlihatkan sebagai berikut

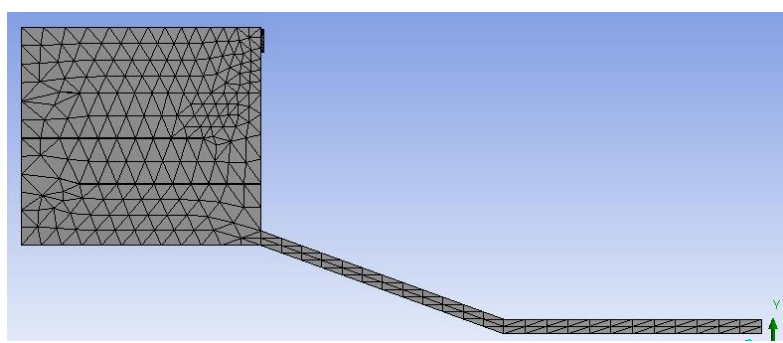

(a)

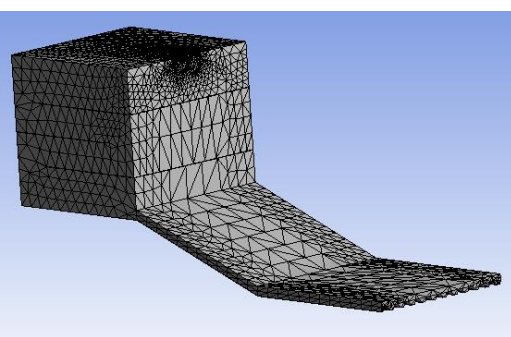

(b)

Gambar 3.2 Mesh dari geometri (a) pandagan depan (b) pandangan 3d

Berdasarkan pengujian eksperimental yang dilakukna pada tanggal 23 Apil 2019 dan pada tempat Gedung Magister Teknik Mesin USU( koordirnat : 3,33 ${ }^{\circ}$ lintang utara dan 98,39 ${ }^{\circ}$ bujur timur). Maka untuk set up tersebut dapat dilihat gambar dibawah ini

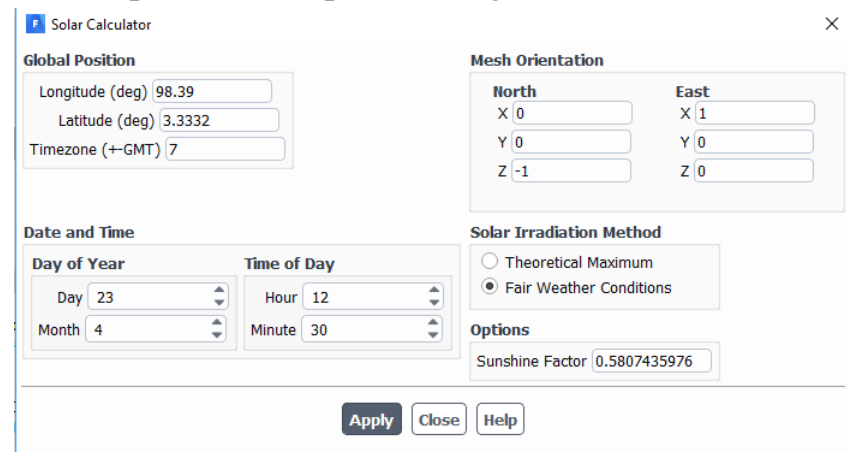

Gambar 3.3 Solar Calculator

Pada bagian pengaturan kondisi batas ini dimasukkan data berupa suhu awal ketika memasuki kolektor serta laju aliran fluida yang telah ditetapkan dan diuji pada eksperimen yang telah dilakukan lebih awal. Pada tabel ini ditunjukan kondisi batas

Tabel 3.1 Batasan kondisi (boundry condition)

\begin{tabular}{|l|ll|}
\hline Boundry condition & Keterangan & \\
\hline Inlet & Tipe & $:$ Velocity Inlet \\
& Temepature & $: 35^{\circ} \mathrm{C}$ \\
& Kecepatan & $: 1 \mathrm{~m} / \mathrm{s}$ \\
\hline Outlet & Tipe & $:$ Mass-outflow \\
& Laju aliran massa & $: 1 \mathrm{~kg} / \mathrm{s}$ \\
\hline Rak 1 & Tipe & $:$ Wall \\
& Mateial & $:$ Alumunium \\
\hline Rak 2 & Tipe & $:$ Wall \\
\hline
\end{tabular}




\begin{tabular}{|l|ll|}
\hline & Material & :Alumunium \\
\hline Rak 3 & Tipe & :Wall \\
& Material & :Alumunium \\
\hline Kaca & Tipe & :Wall \\
& Material & :Kaca \\
\hline Plat Absober & Tipe & :Wall \\
& Material & :Alumunium \\
\hline Gabus & Tipe & :Wall \\
& Material & :Styrofoam \\
\hline
\end{tabular}

\subsection{Processing}

Proses ini merupakan kelanjutan dari pemrosesan di mana geometri dan set-up siap dijalankan pada tahap ini, menggunakan perangkat lunak Fluent ANSYS Student Version 19.1.

\subsection{Post- Processing}

Simulasi numerik dilakukan maka kita akan mendapatkan data suhu pada plat penyerap datar dan plat penyerap sudut.

Berikut ini akan ditampilkan beberapa hasil analisa berupa tampilan distribusi suhu.

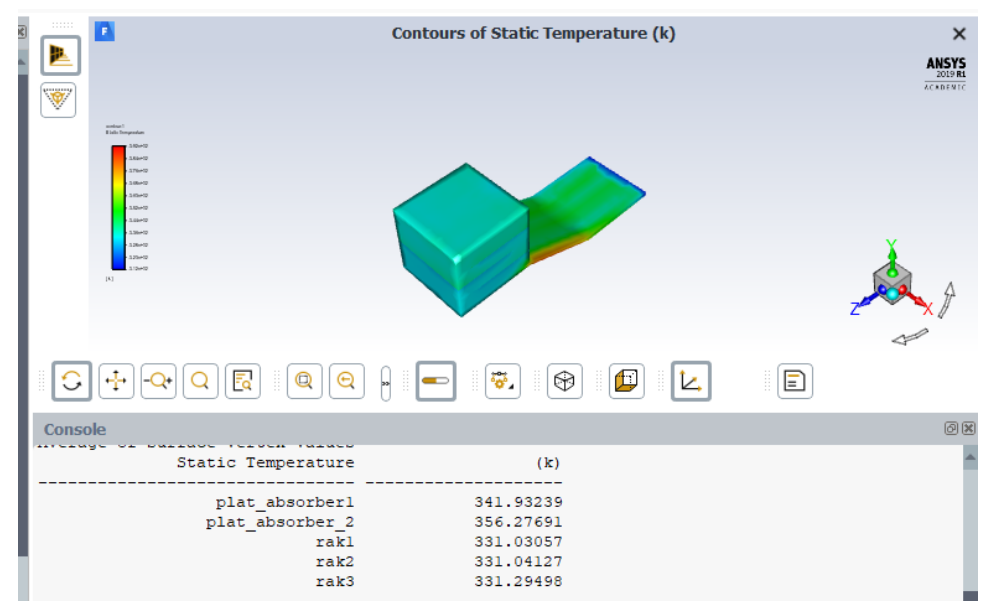

Gambar 3.3 Hasil simulasi

(a)

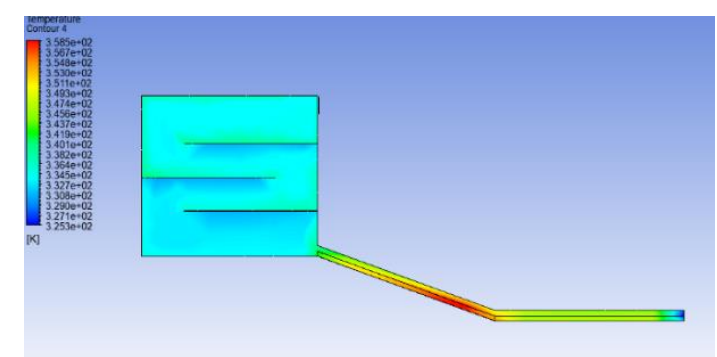

(b)

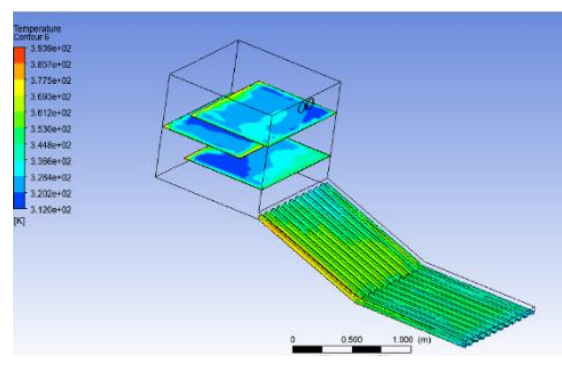

Gambar 3.4 distribusi temperatur: (a) Pandangan depan (b) tiga dimensi

Berikut adalah hasil perbandingan dari pengujian eksperimental dan pengujian numerik

tabel 3.2 Hasil analisa data eksperimental

\begin{tabular}{|c|c|c|}
\hline Parameter perhitungan & $\begin{array}{c}\text { Laju perpindahan panas } \\
\text { (W/mK) }\end{array}$ & Efisiensi \\
\hline$q_{\text {kolektor,terbuang }}$ & 446.97 & \\
\hline quse,kolektor & 1274.064 & \\
\hline
\end{tabular}




\begin{tabular}{|c|c|c|}
\hline$\varepsilon$ kolektor & & 0.74 \\
\hline qruangan,terbuang & 122.32 & \\
\hline quse,ruangan & 1151.744 & 0,90 \\
\hline$\varepsilon_{\text {ruangan }}$ & & \\
\hline
\end{tabular}

Sesuai dengan hasil simulasi yang dipaparkan pada gambar 3.3 dan pada tabel 3.3 kita dapat menghitung laju perpindahan panas kolektor dan ruang pengering. diperoleh hasil analisa simulasi yang dijabarkan tabel 3.4

Tabel 3.3 Temperatur alat pengering pada simulasi numerik

\begin{tabular}{|l|l|}
\hline Titik pengukuran temperatur & Nilai temperature $\left({ }^{\circ} \mathrm{C}\right)$ \\
\hline $\mathrm{T}_{\mathrm{p}, 0}$ & 68,9 \\
\hline $\mathrm{T}_{\mathrm{p}, 20}$ & 83.27 \\
\hline $\mathrm{T}_{\text {rak1 }}$ & 58,03 \\
\hline $\mathrm{T}_{\text {rak2 }}$ & 58,04 \\
\hline $\mathrm{T}_{\mathrm{rak} 3}$ & 58,29 \\
\hline
\end{tabular}

Tabel 3.4 Perhitungan Laju perpindahan panas dan efisiensi beradasarkan simulasi

\begin{tabular}{|l|l|l|}
\hline $\begin{array}{l}\text { Parameter } \\
\text { Perhitungan }\end{array}$ & Laju perpindahan panas (W/mK) & Efisiensi \\
\hline qkolektor,terbuang & 462.54 & \\
\hline quse,kolektor & 1258.494 & \\
\hline$\varepsilon_{\text {kolektor }}$ & & 0.73 \\
\hline q $_{\text {ruangan,terbuang }}$ & 127.417 & \\
\hline quse,ruangan $^{\varepsilon_{\text {ruang }}}$ & 1131.077 & \\
\hline
\end{tabular}

\section{KESIMPULAN DAN SARAN}

\subsection{Kesimpulan}

1. Proses pengamatan yang dilakukan pada alat pengering tenaga surya dilakukan untuk melihat perkembangan sifat fluida yang terjadi selama proses pengeringan didalam kolektor dan ruang pengering. Adapun titik pengamatan yang diukur temperaturnya berturut-turu sebesar:

a. Plat absorber $0^{\circ} 68,9^{\circ} \mathrm{C}$ dan Plat absorber $20^{\circ} 83.27^{\circ} \mathrm{C}$

b. Rak $158,03^{\circ} \mathrm{C}$, Rak $258,04^{\circ} \mathrm{C}$, dan Rak $358,29^{\circ} \mathrm{C}$

2. Laju perpindahan panas yang terjadi pada kolektor dengan perhitungan simulasi adalah 1258.494 Watt, sedangkan laju perpindahan panas ruang pengering dengan perhitungan simulasi adalah 1131.077 Watt. Besar persen ralat dari laju perpindahan panas kolektor adalah $1,2 \%$ dan besar ralat laju perpindahan panas pada ruang pengering adalah $4,1 \%$

3. Efisiensi yag didapatkan dari hasil simulasi pada kolektor adalah $73 \%$, sedangkan efisiensi pada ruang pengering yang didapatkan adalah $89 \%$. besar persen ralat efisiensi kolektor adalah $1.2 \%$ dan besar persen ralat pada efisiensi dari ruang pengering adalah $1.12 \%$

\subsection{Saran}

1. Sebelum melakukan percobaan pada alat yang ingin diteliti, disarankan melakukan kalibrasi pada alat ukur yang digunakan.

2. Karena pada proses simulasi semua asumsi diberikan bersifat sempurna, maka, pada proses penilitan alat pengering tenaga surya, disarankan untuk meminimalisir sumbersumber kerugian yang mungkin terjadi saat pengujian eksperimental

3. Untuk perhitungan yang lebih akurat disarankan untuk menggunakan ANSYS 
4. Bila memungkikan, disarankan untuk menggunakan perangkat keras dengan sistem parallel processor agar dapat menganalisa kasus dengan mesh yang lebih rumit sehingga hasil yang diperoleh yang lebih baik

\section{REFERENSI}

Ambarita, Himsar. 2011a. Energi Surya. Medan: Departemen Teknik Mesin FT USU.

Ambarita, Himsar. 2011b. Perpindahan Panas Konveksi dan Pangantar Alat Penukar Kalor. Medan: Departemen Teknik Mesin FT USU.

Yunus, A. Cengel. 2002. Heat Transfer A Practical Approach. Second Edition. MC Graw Hill, Book Company, Inc: Singapore.

Incropera, F. P., and Dewitt. D. P.. 1196. Fundamentals of Heat and Mass Transfer. Fourth Edition. John Wiley \& Sons. New York. 